University of Nebraska - Lincoln

DigitalCommons@University of Nebraska - Lincoln

USDA National Wildlife Research Center - Staff Publications
U.S. Department of Agriculture: Animal and Plant Health Inspection Service

January 2005

\title{
Husbandry of wild-caught greater sage-grouse
}

\author{
Paul Oesterle \\ USDA/APHIS/WS National Wildlife Research Center \\ Robert McLean \\ USDA/APHIS/WS National Wildlife Research Center \\ Michael Dunbar \\ USDA/APHIS/WS National Wildlife Research Center \\ Larry Clark \\ USDA/APHIS/WS National Wildlife Research Center, clark@metis4u.net
}

Follow this and additional works at: https://digitalcommons.unl.edu/icwdm_usdanwrc

Part of the Environmental Sciences Commons

Oesterle, Paul; McLean, Robert; Dunbar, Michael; and Clark, Larry, "Husbandry of wild-caught greater sagegrouse" (2005). USDA National Wildlife Research Center - Staff Publications. 51.

https://digitalcommons.unl.edu/icwdm_usdanwrc/51

This Article is brought to you for free and open access by the U.S. Department of Agriculture: Animal and Plant Health Inspection Service at DigitalCommons@University of Nebraska - Lincoln. It has been accepted for inclusion in USDA National Wildlife Research Center - Staff Publications by an authorized administrator of DigitalCommons@University of Nebraska - Lincoln. 


\title{
Husbandry of wild-caught greater sage-grouse
}

\author{
Paul Oesterle, Robert McLean, Michael Dunbar, and Larry. Clark
}

\begin{abstract}
This study reports the first successful husbandry and breeding in captivity of wild-caught greater sage-grouse (Controccrcus urophasianus). In October 2003, 21 hatch-year greater sage-grouse were trapped in northwestern Nevada and transported to Fort Collins, Colorado. We held grouse in pens at the United States Department of Agriculture's National Wildiffe Research Center for 8 months. We offered a varied diet, including native food items such as sagebrush (Artemisia tridentata and A. tripartita) and yarrow (Achillea millefolium). We housed grouse in a large flight pen and allowed to them freerange as one flock. Mortality rate was $16.7 \%$. Several of the grouse exhibited breeding behavior, and 13 eggs were laid. We describe the techniques used to house and feed wild-caught sage-grouse. This study has conservation implications for captive breeding of this species of concern.
\end{abstract}

Key words Artemisia, Centrocercus urophasianus, husbandry, sage-grouse, West Nile virus

The greater sage-grouse (Centrocercus urophasianus) is North America's largest grouse. While still common in parts of its range, overall populations have declined 45-80\% since 1950 (Braun 1998). The primary cause for population decline in sage-grouse is loss of habitat owing to cultivation, overgrazing, sagebrush control programs, introduction of exotic plants, and alteration of natural fire regimes (Connelly and Braun 1997). More recently, West Nile virus (WNV) activity has been placing additional pressure on this species (Naugle et al. 2004). While a great deal of information is known about the husbandry of other gallinaceous birds (e.g., Swarbrick 1985, Scheid 1986), little is known about the husbandry of wild sagegrouse. Here we report on our successful efforts to maintain wild-caught sage-grouse in captivity and in getting the sage-grouse to breed in captivity.

\section{Methods}

\section{Animal capture}

The United States Fish and Wildlife Service (USFWS) trapped 21 greater sage-grouse on
Sheldon National Wildlife Refuge in northwestern Nevada on 6-7 October 2003 using the spotlighting-netting technique (Geisen et al. 1982). Each bird was banded and bled via brachial venipuncture, and placed in 1 of 7 Bird N.E.S.T.TM carriers $(82 \times 41 \times 51 \mathrm{~cm}$, Horizon Micro-Environments L.L.C., Crawford, Ga.). They held grouse at the capture site for 1-9 hours, and then drove them by truck for 3 hours to an airfield in Lakeview, Oregon. Grouse were transported by aircraft for 5 hours to Fort Collins, Colorado and driven by truck for 15 minutes to United States Department of Agriculture's National Wildlife Research Center (NWRC). Upon arrival at the NWRC, we weighed the grouse, inspected their plumage characteristics, and determined that all 21 were hatch-year birds according to information presented in Ottomeier and Crawford (1996). We dusted birds with Drione ${ }^{\circledR}$ (Bayer Environmental Science, Montvale, N.J.) to control potential infestation of feather mites and clipped their wing feathers to reduce cage trauma. We arbitrarily divided birds into 2 groups ( $n=$ 10 and 11) and placed them into separate holding pens.

Authors' address: Lnited States Department of Agriculture, Animal and Plant Heaith Inspection Service, Wildlite Services, National Wildlife Research Center, 4101 La Porte Avenue, Fort Collins, CO 80521 , USA; e-mail :or Clark: larry.clark@aphis.usda.gov. 


\section{Housing}

We initially housed grouse in outdoor pens $(12 \times 9 \times 3-4 \mathrm{~m})$. These pens had dirt floors, solid 1-m-high cement walls with an additional $2-\mathrm{m}$ high chain-link fence, and sheet-metal ceilings. In addition, we provided grouse with small wooden shelters $(2.4 \times 1.2 \times$ $1.2 \mathrm{~m}$ ) for cover when staff entered the pens. To prevent birds from flying into walls, we suspended netting $(17 \times 14 \mathrm{~m}, 2.5$ $\mathrm{cm}^{2}$ mesh) from the ceiling to form a tent. We draped the netting to the dirt floor and used cinderblocks for weight to keep tent walls taut. We

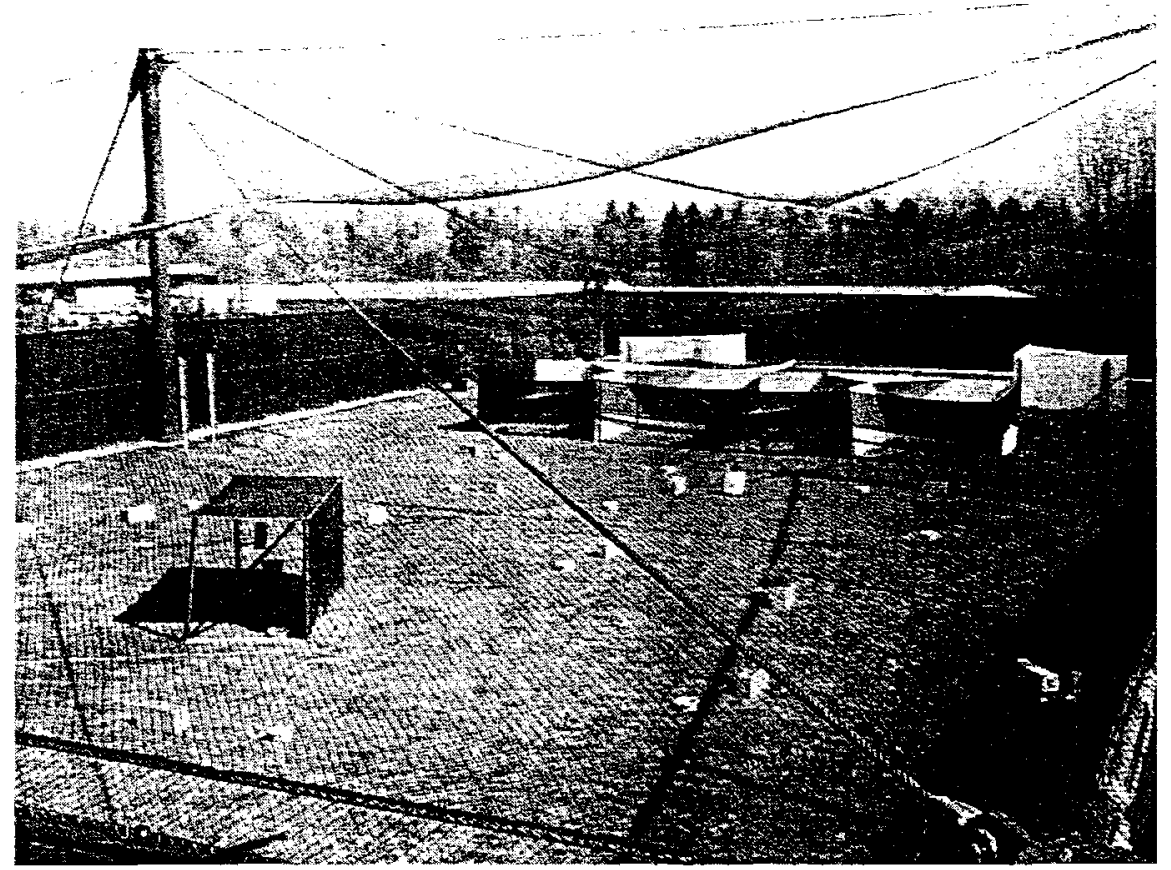

Figure 1. Photo shows flight pen (NWRC, Fort Collins) where the grouse were held for 7 months (23 October 2003-22 May 2004). soon changed this config-

uration so that the walls of the tent were attached to the top of the cement wall using cable ties in one pen. We used no netting in the second pen.

Seventeen days post-capture (DPC), we moved all grouse to an outdoor flight aviary as it became available (Figure 1). The flight pen $(38 \times 19 \times 4-14$ $\mathrm{m}$ ) had a 4-m-high chain-link fence on 3 walls with netting extending from the top of the fence to the peaked ceiling; the fourth wall and ceiling consisted of netting. All walls were covered with $90 \%$ shade cloth ( $4 \mathrm{~m}$ high). We provided 3 shelters and a partial dividing wall $(9.7 \times 1.2 \mathrm{~m})$ for grouse to use for cover. The aviary floor was native soil covered with grass except for a gravel border $(75 \mathrm{~cm}$ wide) along 3 walls. We also provided 6 pine (Pinus) trees (1 $\mathrm{m}$ high) along the north wall for additional cover. We used a raised observation tower with one-way glass located outside of the pen as a blind from which to observe grouse (Figure 2).
Within the flight pen, we constructed 4 small sub-pens $(2.4 \times 2.4 \times 1.2 \mathrm{~m})$ along the dividing wall. Two walls consisted of plywood and 2 of shade cloth. We designed the sub-pens to allow underweight birds to eat without competition. When grouse were moved to the flight pen, we placed 9 birds in these sub-pens, with 2-3 birds per pen. We selected these 9 birds due to weight loss of $>10 \%$ of their arrival weight as well as on the basis of their demonstrating submissive behavior.

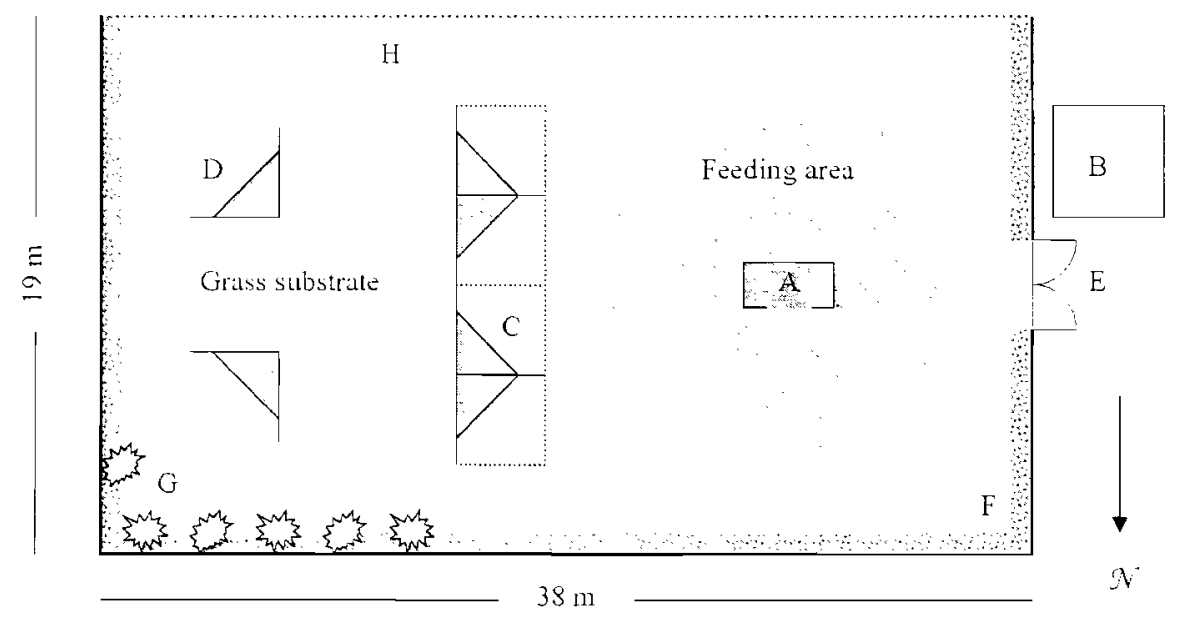

Figure 2. Diagram or Hight pen (NWRC. Fort Collins; 25 October 2003-22 Nay 2004). (A) ieeding shelter with video monitored $5 \mathrm{cal}$ e., $\mathrm{B}$ i observation tower, (C) visual barriers and sub-

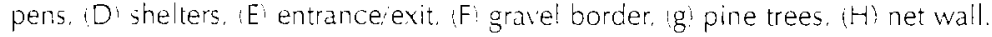


Grouse that were separated into the sub-pens were reunited with the flock within a few dars.

\section{Feeding and maintenance}

We fed the grouse twice daily for the first 11 weeks, after which we reduced feeding to once per day. We offered sagebrush (Artemisia tridentata and $A$. tripartita) cuttings and live plants, live yarrow (Achillea millefolium), chopped mixed greens (various lettuces, spinach, and beet greens), chopped apples, live mealworms, and commercially prepared poultry chick starter (Ranch-Way Feeds Inc, Fort Collins, Colo.). We changed the poultry feed to game bird crumble feed (Ranch-Way Feed Inc, Fort Collins, Colo.) after 1 month. We added green peas to the diet after sagebrush cuttings became unavailable. We also offered alfalfa hay, dandelions, clover, and Purina ${ }^{(B)}$ Moist \& Meaty ${ }^{\text {TM }}$ (Nestlé Purina Petcare Co., St. Louis, Mo.) dog food on an experimental basis.

We provided multiple feeding stations, with the number of food bowls in the pens equaling the number of birds plus one. We spaced bowls 1-2 m apart in the small pens and 3-4 $\mathrm{m}$ apart in the flight pen. In addition, we provided 12 live plants and 12 cut sagebrush stations at each feeding. Water was available ad libitum in a plastic 18.9-liter (5-gallon) poultry water fount. We monitored food intake through visual approximation and quantified it to adjust the amount of food offered at each feeding accordingly.

We collected wild sagebrush cuttings monthly by permit from Roosevelt National Forest, Colorado, and we purchased live sagebrush (260 3.8-liter sized [1-gallon-sized] plants) and yarrow (660 3.8liter-sized [1-gallon-sized] plants) at local greenhouses. Initially, we laid sagebrush cuttings on the ground. Subsequently, we placed cut sagebrush into the hollow cells of cinder blocks. We replaced live yarrow and sagebrush at each feeding and moved them to the Colorado State Division of Forestry greenhouse after they were browsed by the birds to allow for regeneration of leaves.

We took precautions to reduce stress and potential disease exposure. We limited the number of visits into the pens to 1-2 times daily; we moved slowly while servicing the pens and kept noise to a minimum. As a biosecurity measure, staff personnel used footbaths upon entering and exiting pens. We changed footbaths daily and rotated 3 disinfectants: Rocal-D ${ }^{\circledR}$ (Pharmacia and Upjohn, Kalamazoo, Mich.), 1-Stroke Environ ${ }^{\circledR}$ (Steris Corporation, St.
Louis, Mo.), and ChlorhexQ ${ }^{\widehat{B}}$ (First Priority Incorporated, Gilbert, Ill.) on a weekly basis.

\section{Monitoring bird well-being}

We captured and weighed birds on 3, 7 , and 17 DPC; we also placed numbered patagial tags on each individual for identification. In addition, we equipped the flight pen with a video-monitored scale that recorded from dawn to dusk; the scale had a platform on which a food bowl or plant was placed. We positioned a second video camera to record a wide-angle view of the feeding area to observe frequency of foraging trips. We eventually moved this second camera to record nesting activity.

We used the observation tower to monitor the health and behavior of grouse. We observed birds for 20-40 minutes after each feeding. The observer noted feeding behavior as well as any aggressive and dominant behavior, and breeding activities. We defined dominance as one bird's ability to force retreat of a second bird or displace it at feeding, roosting, and watering stations; we defined breeding behavior as displays by males and egg-laying by females. In addition, the staff was able to monitor any potential health issues among the grouse.

\section{Results}

\section{Diet and body weights}

After grouse arrived, they readily ate sagebrush (both wild cuttings and potted plants), yarrow, and mealworms. Grouse stripped the yarrow of its leaves and stems and removed all leaves from the sagebrush plants. After we placed sagebrush cuttings upright in cinder blocks, consumption of sagebrush increased. In addition, grouse used sagebrush in the cinderblocks for cover when they roosted. Grouse did not consume other food items until 2 weeks after their arrival from the field. Once birds became accustomed to their new diet, they ate all the nonpoultry food (i.e., plant material, fruit, mealworms) before the commercial feed. For the 18 grouse housed in the flight pen throughout most of the study, daily consumption for the group was 2 large apples (diced into $0.5 \mathrm{~cm}$ cubes), $100 \mathrm{~g}$ of mixed greens (chopped into $0.5 \mathrm{~cm}$ pieces), 120 $\mathrm{g}$ meal worms, $150 \mathrm{~g}$ frozen peas, 6 yarrow plants, 6 sagebrush plants, and 12 large sprigs of wild sagebrush cuttings. Daily consumption of game bird crumbles was highly variable $(0.2-2.0 \mathrm{~kg})$. We evenly divided game bird food $(2.5 \mathrm{~kg})$ into 19 bowls and provided it to grouse. Grouse would eat 


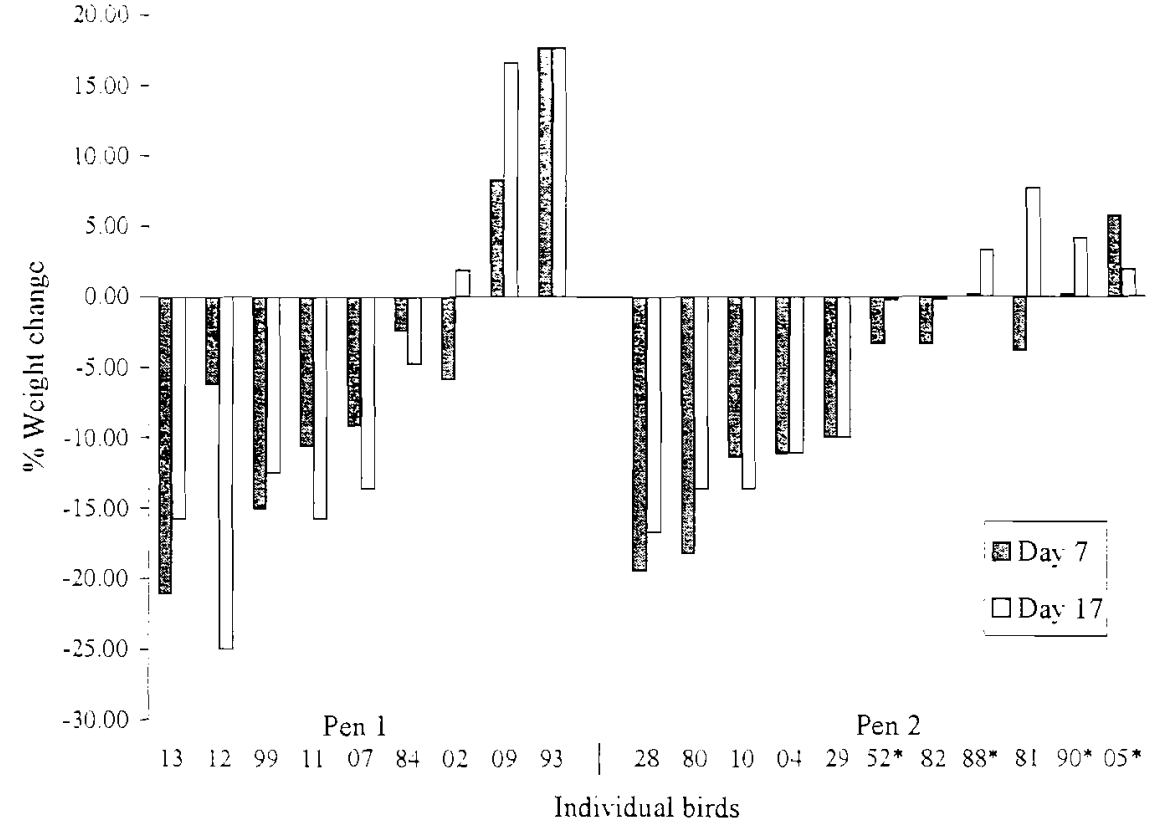

Figure 3. Relative (to day zero) weight changes for greater sage-grouse held in small pen enclosures (NWRC, Fort Collins) during the first 17 days after capture (8-24 October 2003). Bird numbers marked with an asterisk indicate males. All other bird numbers represent females. ume of consumption was minimal.

While grouse were housed in the 2 smaller pens, we observed weight loss among the majority of birds. Nine of the birds lost greater than $10 \%$ of their body weight. However, 3-4 birds in each pen gained weight (Figure 3). Once grouse were moved to the larger flight pen we observed weight gain for all birds. All 4 males and 7 of the females regularly ate while on the scale, giving us an opportunity to monitor their weights nearly daily. However, a few grouse never used the scale feeding station. For these birds we obtained weights at

the larger particles (approximately $\geq 2 \mathrm{~mm}$ ) but leave the smaller particles and "food dust." Clover leaves were eaten, but we only offered them a few times as we lacked a reliable source. Grouse did not eat alfalfa, dandelions, or dog food. Grouse were observed drinking water regularly, but the vol-

the end of the holding period. Although all birds gained weight in the flight pen, there was a substantial difference between highest and lowest gains. The average weight gain for males from October to May was $64 \%$, and females realized a $38 \%$ weight gain (Figure 4).

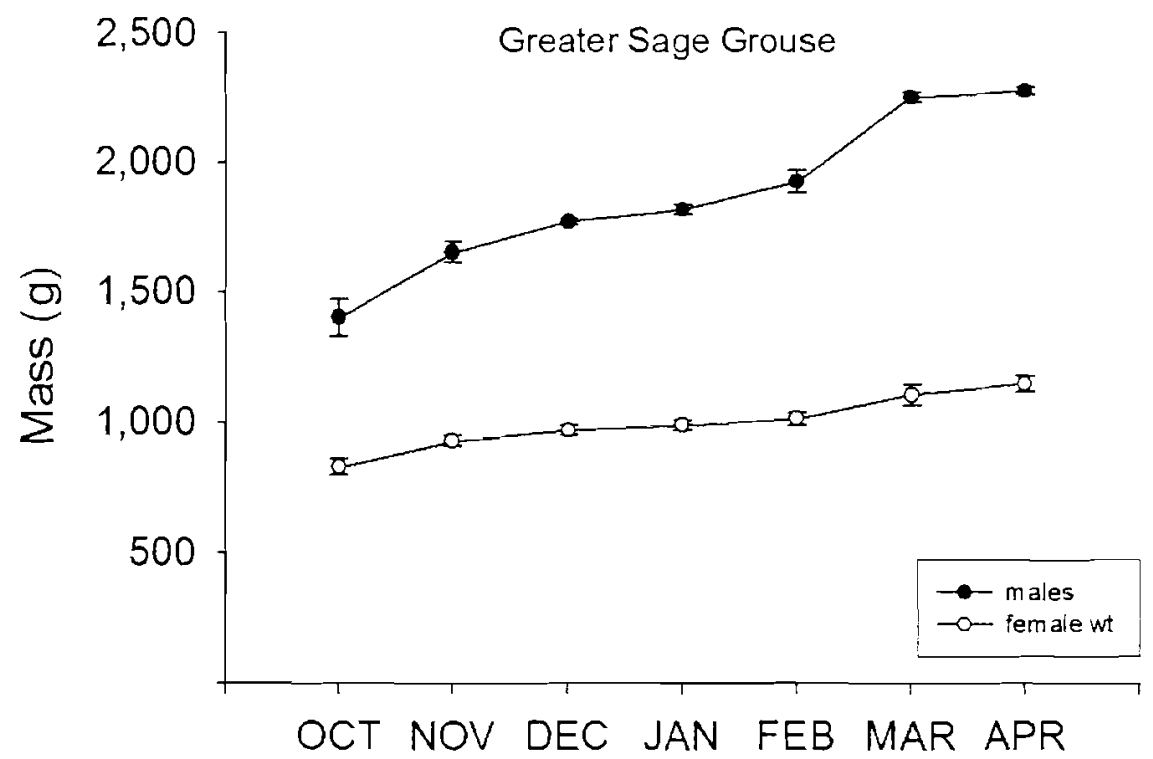

Figure 4. Mean (- standard error mass of greater sage-grouse as a function of sex and time. Values depicted cover the period 25 October 2003-22 May 2004) when the grouse were housed in the larger flight pen INVWRC, Fort Collinsi as one group.

\section{Morbidity and mortality}

The net tent that was hung from the ceiling of one of the original smaller pens to prevent cage trauma produced mixed results. The netting prevented grouse from flushing into the walls, but due to the size of the mesh, birds' heads became entangled as they attempted to escape through the netting

We observed injuries on 2 occasions. One bird injured its wing while in the smaller pen that lacked netting; we suspected cage trauma. A 
second bird developed a leg injury in the flight pen; we suspected it was cage-mate aggression. The wing injury never fully healed while the leg injury gradually improred to normal after 3 weeks. This bird became the dominant bird in the flock shortly after recovery.

Mortality rate of grouse was $16.7 \%$ (6 October 2003-22 May 200 1). Three birds dicd of unknown causes and 3 birds died during handling due to causes independent of husbandry conditions; hence, these birds were not included in calculation of the mortality rate attributable to maintenance husbandry. These latter birds died during extended handling under hot ambient air conditions in preparation for other experiments, apparently from heat stress. These birds had a history of weight gain $(6.5-28.7 \%)$ and were in good condition with no findings for bacteriology or gross pathology. Of the 3 birds dying from unknown etiology, the first died on DPC 5 , having lost $16 \%$ of its body weight. Diagnostic testing indicated bacteremia and coelomitis. The second bird died on DPC 19, having lost $25 \%$ of its body weight. Necropsy indicated pyogranulomatous pneumonia and air saculitis with Aspergillus sp. The third bird died on DPC 35 having lost 5\% of its body weight. Necropsy indicated granulomatous pneumonia and air sacculitis of unknown etiology.

\section{Bebavioral observations}

While staff serviced the pens, grouse used the plywood structures for cover. Once feeding was finished, it usually took 2-30 minutes for birds to approach the food bowls. They typically fed for approximately 15 minutes, after which time they returned to the rear of the pen, often loafing on the gravel border or under the pine trees. The frequency of their foraging trips was every 1-2 hours throughout the day.

Breeding behavior was first observed in January; males displayed by fanning their retrices, holding their filoplumes and yellow eye-combs erect, and inflating their esophageal pouches. Females began laying eggs in late March, and a total of 13 eggs were laid. Based on egg measurements and timing of laying, we believe that 4 different females laid eggs. The first 2 eggs were laid on the ground in separate locations with no apparent nests. Another female laid 6 eggs while nesting material was continually added to the nest, and she began incubating when the fifth egg was laid. Finally, the hen laid 5 eggs in a scrape on the ground but did not incubate them and added no nesting material.

Eleven of the 13 eggs were fertile. We collected the first 2 eggs and artificially incubated them for 14 days; derelopment appeared normal. We sacrificed these eggs prior to hatching. The first nest was naturally incubated for 28 days; 3 eggs hatched but the chicks died within 24 hours, at least in part duc to a late-seasun stium slurm. Because analysis of video tapes indicated that the female from the second nest was not incubating the eggs, we removed all the eggs and artificially incubated them. All eggs subsequently hatched. However, the chicks hatched early on a Sunday morning when minimum staffing was available. As a consequence of the increased interval between monitoring by staff, all chicks died within the incubator owing to drowning in the water source.

Some aggression was observed among birds, and shelters often served as a sanctuary for grouse during aggressive encounters. Hostile exchanges were fewer during the autumn and increased with the advent of spring. Aggressive interactions in autumn and winter consisted of subtle gestures at and around food bowls. In spring, aggressive behavior became more apparent, especially among the 4 males. We frequently observed chasing during displays and at feeding stations. Males chased females as well, both in the feeding area and rear of the pen. One male attacked an incubating female on several occasions, chasing her off the nest. The male would then guard the nest and keep the incubating female away from the nest for as long as 90 minutes. The male would often display around the nest during these events.

Aggression among females also occurred and was usually observed around the feeding area. In addition, 3 different females chased the incubating female from her nest on numerous occasions. The aggressive females acted alone or in pairs and assisted the male during his hostile bouts. The females also guarded the nest to prevent the incubating hen from returning to the nest. Frequently, we saw these females removing nesting material from the nest, and occasionally they ejected eggs from the nest. The incubating female always returned displaced eggs to the nest.

\section{Discussion}

Wild sage-grouse are challenging to house in captivity. Our relative success in keeping the sagegrouse alive was due to 2 factors. First. all of the 
grouse were hatch-year birds. Second, we were able to provide a large outdoor flight pen. We suspect that young birds are behaviorally flexible, so they likely habituated to the caged environment with ease relative to adults. Additionally; the large pen allowed birds to flock together and form social units in large central arenas. Yet the pen also allowed a configuration of barriers that provided partial risual isolation. Grouse utilized this aspect of the pen during aggressive encounters when the subordinate bird would duck behind a visual barrier. Once the submissive bird was out of sight of the dominant bird, pursuit and aggression ended. The visual barriers also allowed for refuge by grouse during maintenance by staff and, presumably, reduced stress in the birds.

Grouse preferred to rest near the gravel edges on the north and east sides of the flight pen. These locations received maximum sunlight from the south and west and, thus, were presumed to be warmer locations. These also were the locations of the 2 nests. We suspect that by providing better visually isolated refugia toward the edges of the pens or by offering better thermal loafing areas in other parts of the pens for other grouse, much of the aggression and harassment toward females incubating eggs could have been averted

Our greatest concern was the ability of the wild caught grouse to adapt to a caged environment. To ease transition from the wild to captivity, we offered grouse a diet they would recognize as food and that would provide adequate nutrition and could be consistently provided. While in the small pen enclosures, grouse were resistant to our efforts to switch them from a natural diet to one of commercial poultry food. Moreover, it became apparent that a hierarchy developed and a few birds prevented the majority from gaining free access to food (Figure 3). It was only after we moved grouse to the flight pen that they readily accepted the poultry food, though they always preferred the noncrumble alternatives. We continued to offer the diverse, enriched diet because of the apparent acceptance by the birds, relative ease of preparation, and continued evidence of weight gain. Thus, it appears that providing sage-grouse with sufficient space to forage without interference by conspecifics is critical to successful maintenance. The 1-2-m distance between feeding stations provided in the small pens was apparently not sufficient to accomplish this goal. The 3-4-m distance between feeding stations provided in the flight pens achieved the goal of noninterference.

The flight pen also provided a natural substrate (grass) that appeared to be important to grouse. We saw grouse pecking at the gravel (possible gritting behavior), moving insects, and eating weeds and grass. Thus, the flight pen prorided a more natural substrate than the small pens. Dust from the small pens' dirt floors may have caused or exacerbated evidence of respiratory distress diagnosed for the 3 birds that died during early phases of captivity.

We depended on behavioral observations to assess grouse behavior. The larger flight pen great ly improved our ability to monitor their activities. We could evaluate birds without causing stress and observe their behavior as well as any potential morbidity. Stress is a concern for all birds in captivity; excess stress can cause a myriad of problems including immunosuppresion and decreased appetite (Siegel 1980). We believe that handling, especially during warm weather, was most stressful activity for the grouse and likely contributed to the deaths of 3 birds during or shortly after handling. Some possible solutions to reduce the stress of capture are to use a funnel system to capture birds at dawn when the temperature is lowest, process them at a secondary site, and return birds to their pen as soon as possible.

\section{Management implications}

The development and improvement of sagegrouse husbandry and possibly captive propagation may be important in the future since grouse populations are declining. The population decline is largely due to loss of habitat, but diseases such as WNV could further increase the decline. Reliable husbandry techniques could provide researchers with more options when studying declining sage grouse populations and provide wildlife managers with options to breed grouse for the purpose of restocking natural habitats. Although we provided an enriched diet in addition to poultry food, we suspect that under appropriate conditions, grouse could be diverted to a completely dry commercial diet. This may be especially likely if the housing substrate is of a natural grass-gravel-dirt composition. Providing $n+1$ feeding stations distanced between 3-4 m apart appeared critical to provide all grouse with feeding opportunities and minimize aggression between birds. Providing visual barriers is important to protect subordinates and incubating females. Better provisioning and spacing of thermal 
loafing sites also may help in providing nesting sites and separating incubating females from other birds. A combination of open common areas for feeding and lekking and areas of visual obstruction will be important to the long-term husbandry and breeding management of sage-grouse. We were able to accomplish this in a $19 \times 38$-m netted outdoor facility housing 18 birds. Because this was a research endeavor. it would be premature to estimate the cost-effectiveness of such a program. However, our results suggest that a cost-effective captive breeding program might be feasible. For example, we suspect that better space management along the outline of the variables discussed above could accommodate more breeding opportunities and larger numbers of birds.

An alternative to the methods discussed here is artificial incubation of wild sage-grouse eggs, allowing for hatching of young in a captive setting. It would potentially decrease the mortalities associated with capture and handling. The difficulty in meeting the nutritional needs of the chicks, however, could offset the gains of reducing stress (Huwer 2004)

Acknowledgments. We thank the United States Fish and Wildlife Service and Sheldon-Hart Mountain National Wildlife Refuge Complex (NWRC) for trapping and transporting grouse, $\mathrm{N}$. Nemeth for providing comments on the manuscript, R. Moench at the Colorado State Forestry Service for allowing us to use their greenhouse, $G$. Hodges at the United States Department of Agriculture's Forest Service for allowing us to collect sagebrush from Roosevelt National Forest, and G. Mason, R. Basaraba, and E. Ehrhart at the Colorado Veterinary Diagnostic Laboratory for their thorough necropsies. We thank the Avian Disease group at NWRC, for all of their hard work caring for the grouse. In addition, we thank the United States Fish and Wildlife Service for providing partial funding of this project.

\section{Literature cited}

Bkaliv, C. E. 1998. Sage grouse declines in western Norch America: What are the problems? Proceedings Western Association of Fish and Wildlife Agencies 78: 139-156.

ConNeldi, J. W. AvD C. E. BRtx. 199-. Long-term changes in sage grouse Centrocercus uropbasiamas populations in western North tmerica. Wildlife Biology 3:229-234

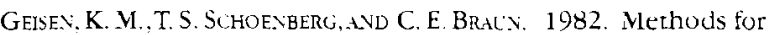
trapping sage grouse in Colorado. Wildlife Sociery Bulletin 10:22 $1-131$.
HLWER. S. 1. 2004. Evaluating greater sage-grouse brood habicat using human-imprinted chicks. Thesis. Colorado State Universicy; Fort Collins: LSA

Sicgle. D. E.. C. L. Alidrduge. B. L. Whlher. T. E. Curvish. B. J

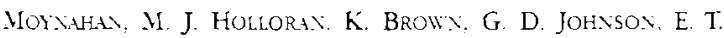

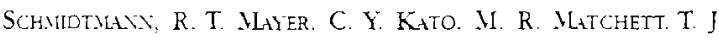
ChrlstuNes: W. E. COOK. T. CReEkyORe, R. D. FHise, E. T. RIYKes, A:D M. S. Borce. 2004. West Nile virus: pending crisis for greater sage-grouse. Ecology Letters 7:70 $4-713$

OTtOMEIER A A.,Alid J A CrawFord. 1996. Revised measurements for classification of age of sage grouse from wings. California Fish and Game 82:61-65

SCHEiD, D.W. 1986. Raising game birds. Seventh edition. Lassiter, Brookfield, Wisconsin, USA.

SIEGEL, H. S. 1980. Physiological stress in birds. BioScience 30: 529-534.

SWARBRICK, O. 1985. Pheasint rearing associated husbandry and disease problems. The Veterinary Record 116:610-617.

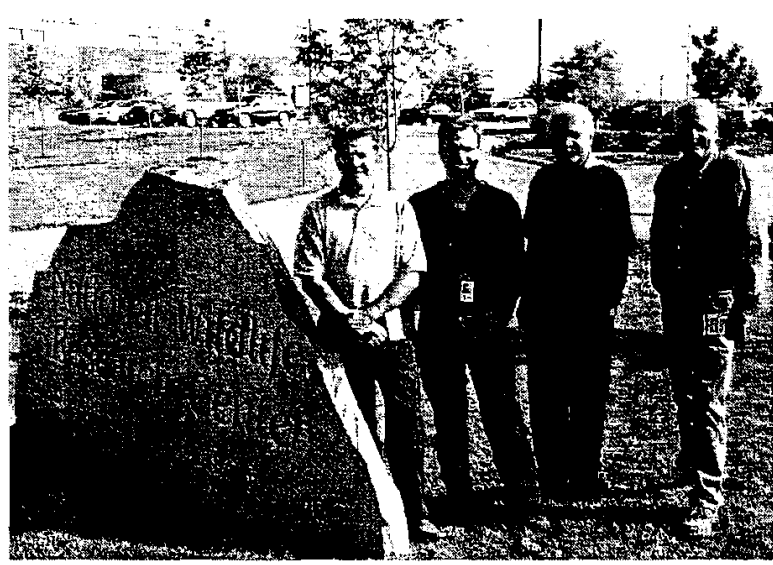

Paul Oesterle (second from left) is a biological science techni cian at the National Wildlife Research Center (NWRC). He worked in Hawaii as a biologist raising and releasing endangered passerines for 5 years. He received a B.S. from the University of California-Davis (1994). Robert Mclean (third from left) is the Program Manager of Wildlife Diseases at the NWRC. His research interests include wild ife disease ecology and wildlife diseases of public health and animal health importance to the U.S. Michael R. (Mike) Dumbar (far right) received his M.S. in wildlife ecology from Oklahoma State University and his D.V.M. from Washington State University. Mike is currently a research wildlife biologist and project leader for bovine tuberculosis and rabies in wildlife. His research interests include nutrition and disease in free-ranging wildlife, including ungulates, carnivores, and upland game. Larry Clark (far left) is Assistant Director of the NWRC. Larry completed his B.S. in zoology from the University of Maryland, M.S. in biology from Northern Arizona University, and Ph.D. in evolutionary ecologr and population biology from the University of Pennsvlvania. His research interests include chemical ecology and sensory biology of vertebrates and wildlife disease ecology.

Associate editor: Giuliano 